\title{
Ellipsis
}

2021

\section{The Ways I Could Be Held}

John Cape

University of New Orleans

Follow this and additional works at: https://scholarworks.uno.edu/ellipsis

\section{Recommended Citation}

Cape, John (2021) "The Ways I Could Be Held," Ellipsis: Vol. 46 , Article 3.

DOI: https://doi.org/10.46428/ejail.46.03

Available at: https://scholarworks.uno.edu/ellipsis/vol46/iss1/3

This Poetry is brought to you for free and open access by the Department of English and Foreign Languages at ScholarWorks@UNO. It has been accepted for inclusion in Ellipsis by an authorized editor of ScholarWorks@UNO. For more information, please contact scholarworks@uno.edu. 


\title{
The Ways I Could Be Held by Jack Cape
}

Sometimes -

\author{
(Forgive me)
}

I think of all the ways I could be held.

If I were to be baptized in the blue-green waters of the Aegean tomorrow, Surely there would be hands placed beneath me -

So I could float.

The musky embrace of a new lover.

The gentle moment when he lays his head upon my chest.

It all seems so fantastical now.

A faraway castle

In a distant land. 